International Journal of

Supply Chain

Management

(IJSCM)

INFLUENCE OF PUBLIC PROCUREMENT AND ASSET DISPOSAL ACT ON PERFORMANCE OF EXECUTIVE STATE CORPORATIONS IN KENYA

Stevens Omondi Musewe and Dr. Geoffrey Gekara

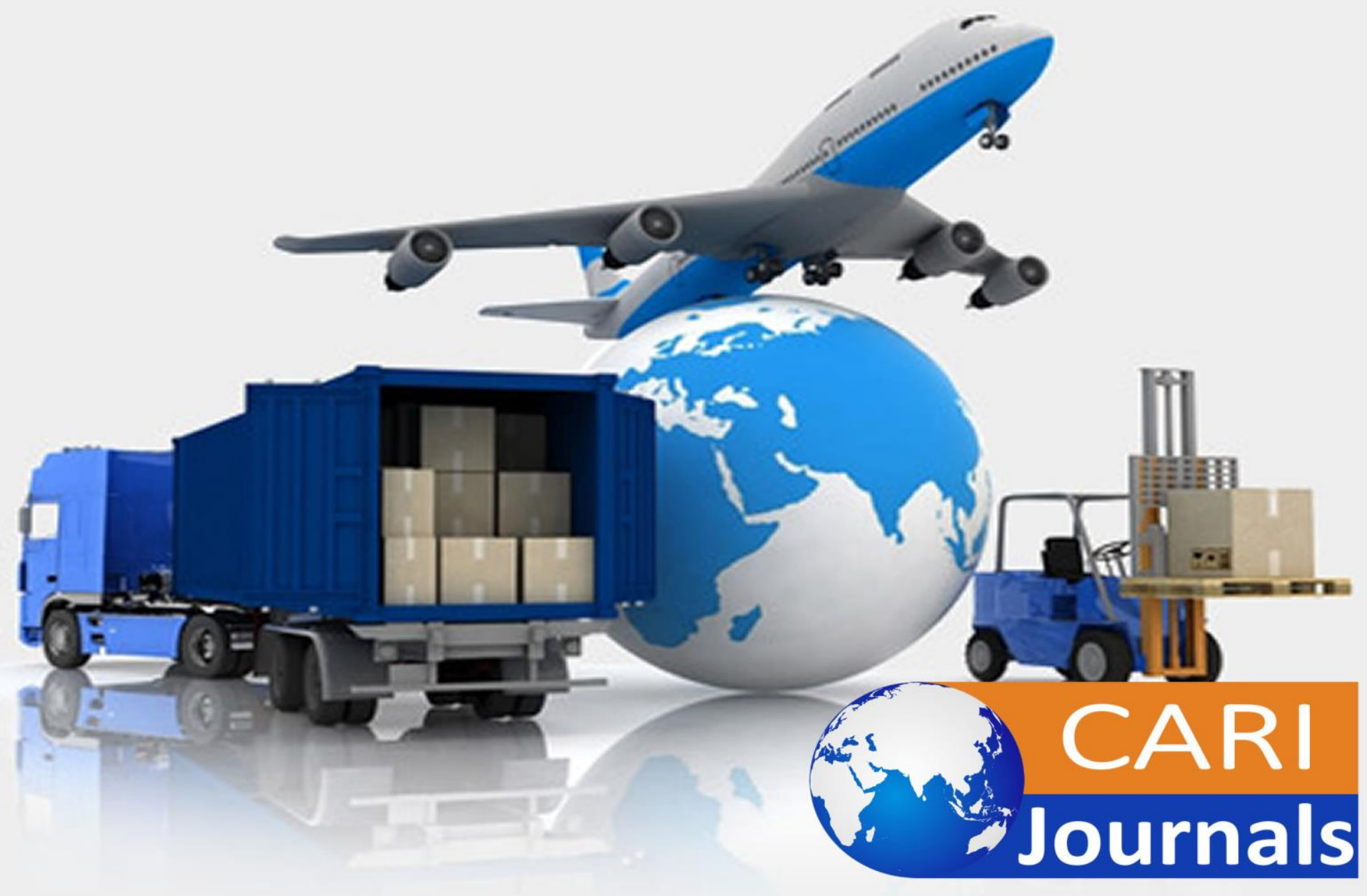




\title{
Influence of Public Procurement and Asset Disposal Act on Performance of Executive State Corporations in Kenya
}

\author{
${ }^{1 *}$ Stevens Omondi Musewe \\ ${ }^{1}$ Post Graduate Student: Department of Procurement and Logistics \\ Jomo Kenyatta University of Agriculture and Technology \\ *Corresponding Author's E-mail: Stevens.musewe@karlo.org \\ ${ }^{2}$ Dr. Geoffrey Gekara \\ Lecturer, Department of Procurement and Logistics \\ Jomo Kenyatta University of Agriculture and Technology
}

\begin{abstract}
Purpose: The purpose of the study was to examine influence of public procurement and asset disposal Act on performance of executive state corporations in Kenya with an aim of making recommendations on proper use.

Methodology: The study employed a descriptive research design targeting the all 62 executive state corporations operating in Kenya. Data was collected from heads of procurement and their deputies in the entities. The researcher preferred this method because it allowed an in-depth study of the subject. Data was collected using self-administered questionnaires. Structured questionnaires were used to collect data. Data was analyzed using descriptive and inferential statistics. Quantitative data was analyzed using multiple regression analysis. The qualitative data generated was analyzed by use of Statistical Package of Social Sciences (SPSS) version 22. The response rate of the study was $81 \%$. The findings of the study indicated that regulation bodies, methods of procurement, preferences and reservations and disposal of assets have a positive relationship with performance of executive state corporations in Kenya.
\end{abstract}

Results and conclusion: The independent variables reported $\mathrm{R}$ value of 0.846 indicating that there was perfect relationship between dependent variable and independent variables. R square value of 0.715 means that $71.5 \%$ of the corresponding variation in performance of executive state corporations in Kenya can be explained or predicted by (preferences and reservation, regulation bodies, disposal of assets and methods of procurement) which indicated that the model fitted the study data. The results of regression analysis revealed that there was a significant positive relationship between dependent variable and independent variable at $(\beta=0.715), p=0.000<0.05)$. The findings of the study indicated that logistics information system, freight management, distributor base rationalization and transport planning have a positive relationship with performance of freight forwarding companies in Kenya.

Unique contribution to theory, policy and practice: Finally, the study recommended that public institutions should embrace regulation bodies, methods of procurement, preferences and 
International Journal of Supply Chain and Logistics

ISSN 2520-3983 (Online)

Vol. 5, Issue No.2, pp 23 - 41, 2021

$\underline{\text { www.carijournals.org }}$

reservations and disposal of assets so as to improve performance of executive state corporations and further researches should to be carried out in other public institutions to find out if the same results can be obtained.

Keywords: regulation bodies, methods of procurement, preferences and reservations and disposal of assets.

\subsection{INTRODUCTION}

Procurement concept has continued to evolve at a faster rate due to changing nature of the procurement world (Mcloughlin \& Batley, 2012). Compliance to procurement Acts has remained to be a routine practice of small and well-established firms from developed and developing countries of the world. Companies that do not observe regulations of procurement Acts in any countries are likely to experience procurement planning setbacks that contribute to deteriorating performance of firms in terms of efficiency and effectiveness, return on investment, profits generated, employee motivation, diversification, product development and maintenance of service standards (Mamiro, 2010).

The earliest public procurement order was found in Syria written on a red clay tablet dates from between 2400 and 2800 B.C. The purchase order was for "50 jars of fragrant smooth oil for 600 small weights in grain" (Coe, 1989). In addition to the history of procurement was the emergence of the silk trade between China and a Greek colony in 800 B.C. (Coe, 1989).

The rise of procurement to a key function in the private and manufacturing industry in the longterm goal of considerable attention since the 1990s. Gadde and Hakansson (2004), unlike in the public sector procurement and supply chain management. While the Public Contract Law Journal dates back to 1981 and Public Procurement Law Review to 1992, both had anchorage in the legal and regulatory disciplines. It was noted that there was differentiation between public procurement and private sector procurement in the last decade (Thai \& Grimm, 2001).

According to Makori (2011), public procurement systems are inherently complex and dynamic due to the multiplicity of objectives they have to achieve. For instance, the main motive of public procurement is to serve the public through a political purpose and the general well-being of the society unlike privately funded projects whose raison d'être is the profit motive. Public service agencies aim at making the best use of 'value for money' for the members of the public this involves client satisfaction, public interest, fair play, honesty, justice and equity (Korosec \& Bartle, 2003).

\subsection{Statement of the Problem}

A World Bank survey (2016), of government and civil representatives in the 60 developing countries confirmed that misappropriation of resources is one of the greatest obstacles to successful public procurement management. The procurement function of an enterprise is one area that is targeted second most by fraudsters (Plavsic, 2014). In Kenya state corporations accounted for 20\% of the country's Gross Domestic Product (GDP), provided employment opportunities to about 300,000 people in the formal sector and 3.7 million persons in the informal sectors of the economy 
(GoK, 2014). However, state corporations in Kenya have been experiencing a myriad of problems including corruption, nepotism and mismanagement (Rotich, 2011).

The Systems Audit for State law Office (SLO), 2015/2016 Report revealed losses of Kshs 18 million through irregular procurements in financial year (FY) 2018/2019. Earlier, in FY 2014/2013, SLO had lost Kshs 8 million due to inefficiencies. This raises questions on the level of prudent public procurement management practices of SLO's procurement system as a state corporation. The situation is one of loss, fraud, theft and gross mismanagement which are hampering improved and sustained procurement performance and service delivery (PPOA, 2009).

The Kenyan government acknowledges that over the years there has been poor performance in the public sector, especially in the management of public resources which has hindered the realization of sustainable economic growth (GoK, 2012). The government reiterates in the economic recovery strategy some of the factors that adversely affect the performance of the public sector. These include excessive regulations and controls, frequent political interference, poor management, outright mismanagement and bloated staff establishment.

However, these measures have not provided a framework for guiding behavior towards attainment of results or ensured accountability in the use of public resources and efficiency in service delivery. The initiatives for instance lack the performance information system, comprehensive performance evaluation system and performance incentive system (GoK, 2014). Currently, Kenya loses billions of taxpayers' money to improper procurement process, specifically poor public procurement management practices. This commonly happens in the country's state corporations due to issues, such as, litigations, contract cancellations and substandard service or product delivery.

Previous research by McGrath and MacMillan (2010) in the UK, on the survey of the use of public procurement and asset disposal Act in public procurement management, shows that use of the Act in their processes improved performance of public agencies by $72 \%$, while in Kenya, no empirical research has been undertaken to reliably quantify the influence of public procurement and asset disposal Act on performance. It is against this backdrop that this study intends to look at the influence of public procurement and asset disposal Act on performance of executive state corporations in Kenya.

\subsection{Objectives of the Study}

i. To assess the influence of regulation bodies on performance of executive state corporations in Kenya.

ii. To establish the influence of methods of procurement on performance of executive state corporations in Kenya.

iii. To determine the influence of preferences and reservations on performance of executive state corporations in Kenya.

iv. To evaluate the influence of disposal of assets on performance of executive state corporations in Kenya. 
International Journal of Supply Chain and Logistics

ISSN 2520-3983 (Online)

Vol. 5, Issue No.2, pp 23 - 41, 2021

$\underline{\text { www.carijournals.org }}$

\subsection{LITERATURE REVIEW}

\subsection{Public Interest Theory}

The public interest theory was developed by A.C. Pigou (1932). The author believed that regulations are prepared in the public interest when they are requested by the public to correct inefficient practices. It is understood that regulations benefit the whole society instead of the interest of any individual. This theory has been passed down from a previous generation of economists to the current generation of lawyers. This theory holds that regulation is provided in response to public demand for the correction of inefficient management of public procurement. It is assumed that regulators such as KISM have sufficient information and control powers to effectively promote the public interest. It also assumes that regulators are benevolent and aim to pursue public interest (Mark, 2013).

\subsection{Public Procurement and Asset Disposal Act}

\subsubsection{Regulation Bodies and Performance of Executive State Corporations}

According to research by Wanjohi (2012) the following key issues affected the regulation policy among the state corporations. First inadequate training of procurement staff in organization had affected the the performance of state corporations, second is incompetency of procurement staff in our organization has affected the performance of state corporations and third is failure to employ good strategic sourcing practices in organizations has affected the performance of state corporations as envisaged even as elaborated in the current PPADA of 2015 (Ogachi, 2011).

\subsubsection{Methods of Procurement and Performance of Executive State Corporations}

According to Afriyie (2015), it is a method that is appropriately used for projects that are specialized in nature, requires the safety of the public which wouldn't be safe to have a tender that is open competitive. It can also be used for projects which are urgent in nature, which has a limited number of potential contractors and lastly used mostly when using a competitive method which is open fails to award a contract for a project. Restricted tendering is mostly used when the value and the conditions are not justifiable to the open tendering where by bids are obtained directly without floating the tender to the public. Here the procuring entity uses its database of pre-qualified providers who are directly invited to tender

\subsubsection{Preferences and Reservations and Performance of Executive State Corporations}

The According to Lysons et al (2013), awareness is defined as knowing something; knowing that something exists and is important; being interested in something. Market opportunity awareness is a combination of commercial awareness and situation awareness which is defined as perception of environmental elements with respect to time and space, comprehension of their meaning and projection of their status after some variables have changed (Mahmood, 2010). 


\subsubsection{Disposal of Assets and Performance of Executive State Corporations}

According Susan and Namusonge (2014) carried out a study on factors affecting the Rate of Disposal of Assets in Public Sector Organizations focusing on Yatta Sub- County- Kenya. The study adopted a census was carried out on all the 28 Government Departments whereby 60 employees who were considered to have relevant information to the study were taken as the respondents. Questionnaires, interview guide and observation schedule were used to collect data. The findings of the study indicated that, the rate of disposal in public sector organizations in Yatta sub- county was low and that the process of procurement planning for disposal was reported as long and tedious.

\subsection{Operationalization of Variables}

\section{Regulation Bodies}

- Public Procurement Regulatory Authority

- Kenya Institute of Supplies Management

- National Treasury

\section{Methods of Procurement}

- Open Tender

- Restricted Tendering

- Direct Procurement

\section{Preferences and Reservation}

- Requirements

- Awareness and Sensitization

- Capacity of the Groups

\section{Disposal of Assets}

- Disposal Committee

- Disposal Procedure

- Restrictions on Disposal

Independent Variables

Dependent Variable

\section{Figure 1: Conceptual Framework}

Source: (Author, 2020) 


\subsection{METHODOLOGY}

The study employed a descriptive research design targeting the all 62 executive state corporations operating in Kenya. Data was collected from heads of procurement and their deputies in the entities. The researcher preferred this method because it allowed an in-depth study of the subject. Data was collected using self-administered questionnaires. Structured questionnaires were used to collect data. Data was analyzed using descriptive and inferential statistics. Quantitative data was analyzed using multiple regression analysis. The qualitative data generated was analyzed by use of Statistical Package of Social Sciences (SPSS) version 22.0. The response rate of the study was $81 \%$. The findings of the study indicated that regulation bodies, methods of procurement, preferences and reservations and disposal of assets have a positive relationship with performance of executive state corporations in Kenya.

The research used a multiple regression model.

$$
Y=\beta_{0}+\beta_{1} X_{1}+\beta_{2} X_{2}+\beta_{3} X_{3}+\beta_{4} X_{4}+\varepsilon
$$

Where:

$$
\begin{array}{ll}
\mathrm{Y} & =\text { Performance of Executive State Corporations } \\
\beta 0 & =\text { Constant } \\
\beta 1, \beta 2, \beta 3, \beta 4 & =\text { Beta Coefficients } \\
X_{1} & =\text { Regulation Bodies } \\
X_{2} & =\text { Methods of Procurement } \\
X_{3} & =\text { Preferences and Reservations } \\
X_{4} & =\text { Disposal of Assets } \\
\varepsilon & =\text { Error Term }
\end{array}
$$




\subsection{RESULTS FINDINGS}

\subsection{Descriptive Statistics}

\subsubsection{Preferences and Reservation}

The first objective of the study was to assess the influence of preferences and reservation on performance of executive state corporations in Kenya. The respondents were asked to indicate to what extent did preferences and reservation influence performance of executive state corporations. Results indicated that majority of the respondents $25 \%$ agreed that it was to a very great extent, $27 \%$ said that it was to a great extent, $35 \%$ said it was moderate, while little extent and not all were at $5 \%$ and $8 \%$ respectively.

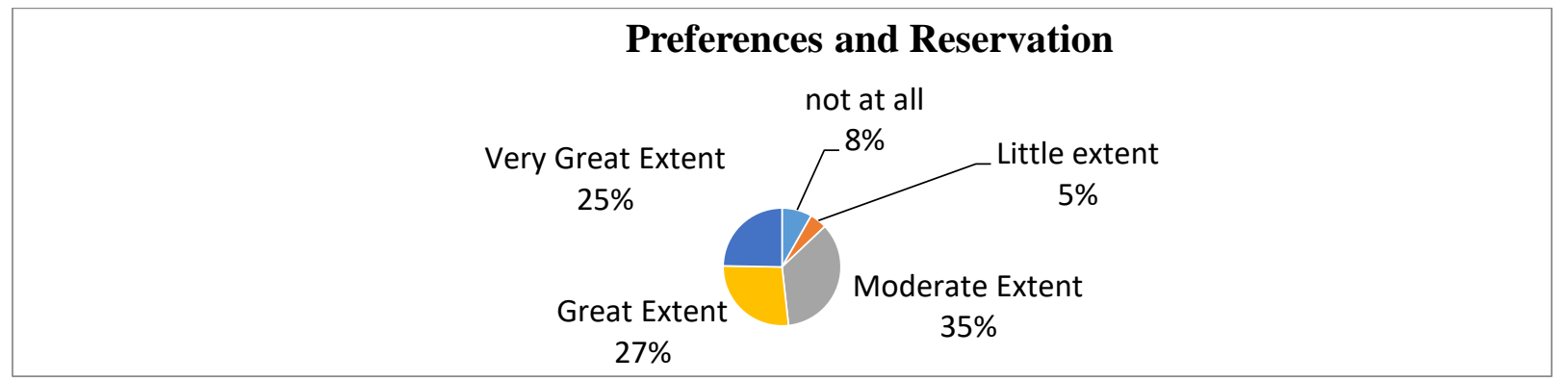

\section{Figure: 1: Preferences and Reservation}

The respondents were also asked to comment on statements regarding preferences and reservation influence on performance of executive state corporationsin Kenya. The responses were rated on a Likert scale and the results presented in Table 4.6 below. It was rated on a 5-point Likert scale ranging from; $1=$ strongly disagree to $5=$ strongly agree. The scores of 'strongly disagree' and 'disagree' have been taken to represent a statement not agreed upon, equivalent to mean score of 0 to 2.5. The score of 'neutral' has been taken to represent a statement agreed upon, equivalent to a mean score of 2.6 to 3.4. The score of 'agree' and 'strongly agree' have been taken to represent a statement highly agreed upon equivalent to a mean score of 3.5 to 5 .

The respondents were asked to indicate their descriptive responses for preferences and reservation. The result revealed that majority of the respondent with a mean of (4.3) agreed with the statement that having requirements plays a significant role in customer satisfaction. The measure of dispersion around the mean of the statements was 1 indicating the responses were varied. The result revealed that majority of the respondent with a mean of (3.6) agreed with the statement that Having awareness and sensitization plays a significant role in customer satisfaction. The measure of dispersion around the mean of the statements was 1.4 indicating the responses were varied. The result revealed that majority of the respondent with a mean of (3.8) agreed with the statement that Having capacity of the groups confirmed plays a significant role in customer satisfaction. The measure of dispersion around the mean of the statements was 1.3 indicating the responses were varied. 
International Journal of Supply Chain and Logistics

ISSN 2520-3983 (Online)

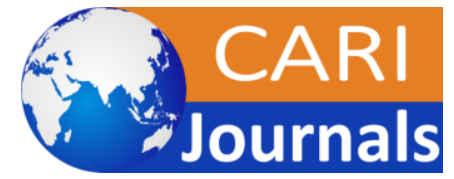

Vol. 5, Issue No.2, pp 23 - 41, 2021

www.carijournals.org

The result revealed that majority of the respondent with a mean of (3.0) agreed with the statement that Having requirements plays a significant role in improving market share. The measure of dispersion around the mean of the statements was 1.4 indicating the responses were varied. The result in table 4.5.1 revealed that majority of the respondent with a mean of (4.2) agreed with the statement that Having awareness and sensitization plays a significant role in improving market share. The measure of dispersion around the mean of the statements was 1 indicating the responses were varied. The result revealed that majority of the respondent with a mean of (3.7) agreed with the statement that Having capacity of the groups confirmed plays a significant role in improving market share. The measure of dispersion around the mean of the statements was 1 indicating the responses were varied.

The result revealed that majority of the respondent with a mean of (3.4) agreed with the statement that Having requirements plays a significant role in increasing profitability. The measure of dispersion around the mean of the statements was 1.3 indicating the responses were varied. The result revealed that majority of the respondent with a mean of (3.8) agreed with the statement that Having awareness and sensitization plays a significant role in increasing profitability. The measure of dispersion around the mean of the statements was 1.2 indicating the responses were varied. The result revealed that majority of the respondent with a mean of (3.8) agreed with the statement that Having capacity of the groups confirmed plays a significant role in increasing profitability. The measure of dispersion around the mean of the statements was 1.2 indicating the responses were varied. However, the variations in the responses were varied as shown by an average standard deviation of 1.5 and an average mean of 3.8. These findings imply that preferences and reservation were at the heart of the organizations. The findings agree with Knudsen (2015) that using preferences and reservation as per the Act is prudent and increases compliance significantly.

\section{Table 1: Preferences and Reservation}

\begin{tabular}{lcc}
\hline Statements & Mean & Std. Deviation \\
\hline $\begin{array}{l}\text { Having requirements plays a significant role in customer satisfaction } \\
\text { Having awareness and sensitization plays a significant role in customer }\end{array}$ & 4.3 & 1.0 \\
$\begin{array}{l}\text { satisfaction } \\
\text { Having capacity of the groups confirmed plays a significant role in }\end{array}$ & 3.6 & 1.4 \\
$\begin{array}{l}\text { customer satisfaction } \\
\text { Having requirements plays a significant role in improving market share }\end{array}$ & 3.0 & 1.3 \\
$\begin{array}{l}\text { Having awareness and sensitization plays a significant role in improving } \\
\text { market share }\end{array}$ & 4.2 & 1.0 \\
$\begin{array}{l}\text { Having capacity of the groups confirmed plays a significant role in } \\
\text { improving market share }\end{array}$ & 3.7 & 0.5 \\
$\begin{array}{l}\text { Having requirements plays a significant role in increasing profitability } \\
\text { Having awareness and sensitization plays a significant role in increasing } \\
\text { profitability }\end{array}$ & 3.4 & 1.3 \\
$\begin{array}{l}\text { Having capacity of the groups confirmed plays a significant role in } \\
\text { increasing profitability }\end{array}$ & 4.1 & 4.3 \\
Average & 3.8 & 1.2 \\
\hline
\end{tabular}




\subsubsection{Regulation Bodies}

The second objective of the study was to investigate the influence of Regulation bodies on performance of executive state corporations in Kenya. The respondents were asked to indicate to what extent Regulation bodies influenced performance of executive state corporations in Kenya. Results indicated that majority of the respondents $31 \%$ agreed that it was to a very great extent, $36 \%$ said that it was to a great extent, $23 \%$ said it was moderate, while little extent and not all tied at $5 \%$.

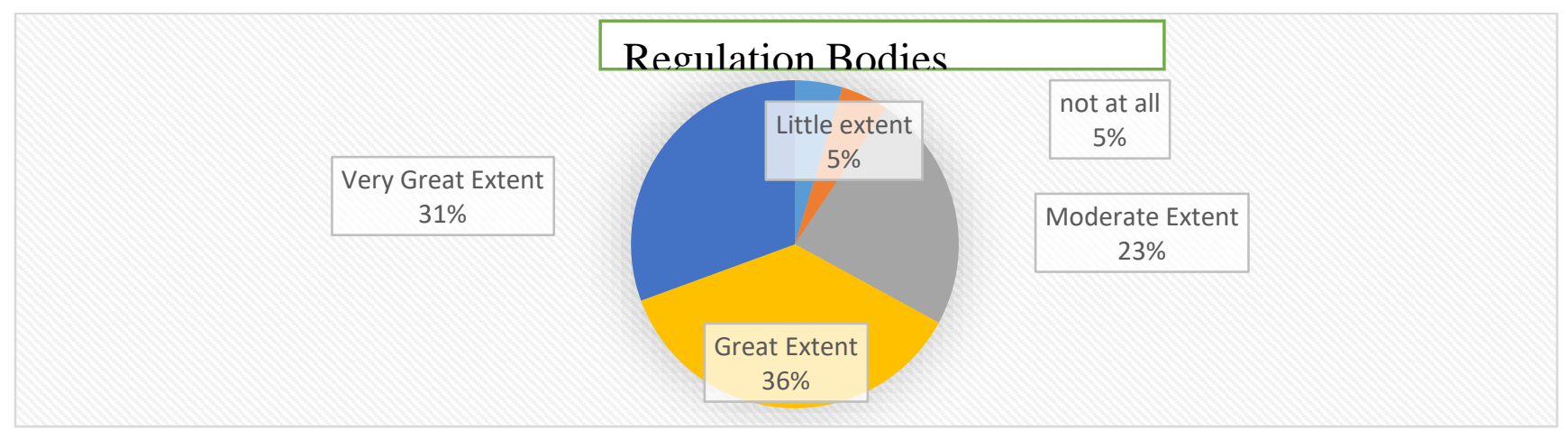

\section{Figure 2: Regulation Bodies}

The respondents were also asked to comment on statements regarding Regulation bodies influence on performance of executive state corporations in Kenya. The respondents were asked to indicate descriptive responses for Regulation bodies. The result revealed that majority of the respondents as indicated by a mean of (3.8) indicated that they agreed with the statement that existence of public procurement regulatory authority plays a significant role in customer satisfaction. The responses were varied as measured by standard deviation of 1.1. The result revealed that majority of the respondents as indicated by a mean of (3.6) indicated that they agreed with the statement that existence of Kenya institute of supplies management plays a significant role in customer satisfaction. The responses were varied as measured by standard deviation of 1.1. The result revealed that majority of the respondents as indicated by a mean of (3.7) indicated that they agreed with the statement that support from national treasury plays a significant role in customer satisfaction. The responses were varied as measured by standard deviation of 1.1

The result revealed that majority of the respondents as indicated by a mean of (3.6) indicated that they agreed with the statement that existence of public procurement regulatory authority plays a significant role in improving market share. The responses were varied as measured by standard deviation of 1.2. The result revealed that majority of the respondents as indicated by a mean of (3.6) indicated that they agreed with the statement that existence of Kenya institute of supplies management plays a significant role in improving market share. The responses were varied as measured by standard deviation of 1.2. The result revealed that majority of the respondents as indicated by a mean of (3.5) indicated that they agreed with the statement that support from national treasury plays a significant role in improving market share. The responses were varied as measured by standard deviation of 1.4 . 
The result revealed that majority of the respondents as indicated by a mean of (3.5) indicated that they agreed with the statement that existence of public procurement regulatory authority plays a significant role in increasing profitability. The responses were varied as measured by standard deviation of 1.4. The result revealed that majority of the respondents as indicated by a mean of (3.3) indicated that they agreed with the statement that existence of Kenya institute of supplies management plays a significant role in increasing profitability. The responses were varied as measured by standard deviation of 1.5. The result revealed that majority of the respondents as indicated by a mean of (3.6) indicated that they agreed with the statement that support from national treasury plays a significant role in increasing profitability. The responses were varied as measured by standard deviation of 0.5 .

However, the variations in the responses were varied as shown by an average standard deviation of 1.2 and an average mean of 3.6. This means that Regulation bodies is an important aspect among executive state corporations. These findings imply that Regulation bodies was at the heart of the organizations. They agree with Lysons (2013) that organizations must comply with their regulation bodies. The opportunities for cost savings and operational improvements can be enormous as the impact on profitability is considerable.

\section{Table 2: Regulation Bodies}

\begin{tabular}{lcc}
\hline Statements & Mean & Std. Deviation \\
\hline $\begin{array}{l}\text { Existence of public procurement regulatory authority plays a } \\
\text { significant role in customer satisfaction }\end{array}$ & 3.8 & 1.1 \\
$\begin{array}{l}\text { Existence of Kenya institute of supplies management plays a } \\
\text { significant role in customer satisfaction }\end{array}$ & 3.6 & 1.1 \\
$\begin{array}{l}\text { Support from national treasury plays a significant role in customer } \\
\text { satisfaction }\end{array}$ & 3.7 & 1.1 \\
$\begin{array}{l}\text { Existence of public procurement regulatory authority plays a } \\
\text { significant role in improving market share }\end{array}$ & 3.5 & 1.2 \\
$\begin{array}{l}\text { Existence of Kenya institute of supplies management plays a } \\
\text { significant role in improving market share }\end{array}$ & 3.8 & 1.2 \\
$\begin{array}{l}\text { Support from national treasury plays a significant role in improving } \\
\text { market share plays a }\end{array}$ & 3.5 & 1.4 \\
$\begin{array}{l}\text { Existence of public procurement regulatory authority plays } \\
\text { significant role in increasing profitability }\end{array}$ & 3.5 & 1.4 \\
$\begin{array}{l}\text { Existence of Kenya institute of supplies management plays a } \\
\text { significant role in increasing profitability }\end{array}$ & 3.3 & 1.5 \\
$\begin{array}{l}\text { Support from national treasury plays a significant role in increasing } \\
\text { profitability } \\
\text { Average }\end{array}$ & 3.6 & 0.5 \\
\hline
\end{tabular}


International Journal of Supply Chain and Logistics

ISSN 2520-3983 (Online)

Vol. 5, Issue No.2, pp 23 - 41, 2021

$\underline{\text { www.carijournals.org }}$

\subsubsection{Disposal of Assets}

There was also need to establish how disposal of assets influenced performance of executive state corporations in Kenya as the third objective. The respondents were asked to comment on extent of disposal of assets influence on performance of executive state corporations. Results indicated that majority of the respondents $21 \%$ agreed that it was to a very great extent, $22 \%$ said that it was to a great extent, $21 \%$ said it was moderate; little extent was $28 \%$ and not all at $8 \%$.

\section{Disposal of Assets}

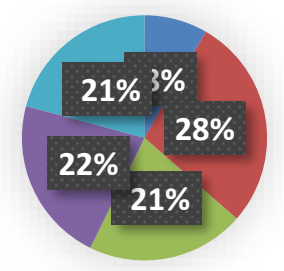

$$
\begin{aligned}
& \text { Not at All } \\
& \text { Little Extent } \\
& \text { Moderate Extent } \\
& \text { Great Extent } \\
& \text { Very Great Extent }
\end{aligned}
$$

\section{Figure 3: Disposal of Assets}

The respondents were asked to indicate their levels of agreement on statements regarding disposal of assets. The results revealed that majority of the respondent (3.9) agreed with the statement that disposal committee plays a significant role in customer satisfaction. The responses were varied as shown by the standard deviation of 1.2. The results revealed that majority of the respondent (3.2) agreed with the statement that disposal procedure plays a significant role in customer satisfaction. The responses were varied as shown by the standard deviation of 1.3. The results revealed that majority of the respondent (4.0) agreed with the statement that restrictions on disposal plays a significant role in customer satisfaction. The responses were varied as shown by the standard deviation of .8.

The results revealed that majority of the respondent (4.2) agreed with the statement that disposal committee plays a significant role in improving market share. The responses were varied as shown by the standard deviation of .9. The results revealed that majority of the respondent (3.7) agreed with the statement that disposal procedure plays a significant role in improving market share. The responses were varied as shown by the standard deviation of .5. The results revealed that majority of the respondent (2.4) agreed with the statement that restrictions on disposal plays a significant role in improving market share. The responses were varied as shown by the standard deviation of 1.3 .

The results revealed that majority of the respondent (3.1) agreed with the statement that disposal committee plays a significant role in increasing profitability. The responses were varied as shown by the standard deviation of 1.2. The results revealed that majority of the respondent (3.2) agreed with the statement that disposal procedure plays a significant role in increasing profitability. The responses were varied as shown by the standard deviation of 1.3. The results revealed that majority of the respondent (3.5) agreed with the statement that restrictions on disposal plays a significant role in increasing profitability. The responses were varied as shown by the standard deviation of 
1.3. The average mean of all the statements was 3.7 indicating that majority of the respondents agreed on disposal of assets influence on performance of executive state corporations in Kenya. However, the variations in the responses were varied as shown by a standard deviation of 1.1. These findings imply that through disposal of assets, companies can improve competitive positioning (Maina, 2018).

Table 3: Disposal of Assets

\begin{tabular}{lcc}
\hline Statements & Mean & Std. Deviation \\
\hline Disposal committee plays a significant role in customer satisfaction & 3.9 & 1.2 \\
Disposal procedure plays a significant role in customer satisfaction & 3.2 & 1.3 \\
Restrictions on disposal plays a significant role in customer satisfaction & 4.0 & 0.8 \\
Disposal committee plays a significant role in improving market share & 4.2 & 0.9 \\
Disposal procedure plays a significant role in improving market share & 3.7 & 0.5 \\
Restrictions on disposal plays a significant role in improving market & & \\
share & 2.4 & 1.3 \\
Disposal committee plays a significant role in increasing profitability & 3.1 & 1.2 \\
Disposal procedure plays a significant role in increasing profitability & 3.2 & 1.3 \\
Restrictions on disposal plays a significant role in increasing profitability & 3.5 & 1.3 \\
Average & $\mathbf{3 . 7}$ & $\mathbf{1 . 1}$ \\
\hline
\end{tabular}

\subsubsection{Methods of Procurement}

There was also need to establish how methods of procurement influences performance of executive state corporations in Kenya. The respondents were also asked to comment on statements regarding methods of procurement influenced performance of executive state corporations. Results also showed that $3 \%$ of respondents indicated to very great extent, great extent was at $12 \%$, moderate extent was $37 \%$, while little extent was at $27 \%$ and not at all was at $21 \%$.

\section{Methods of Procurement}

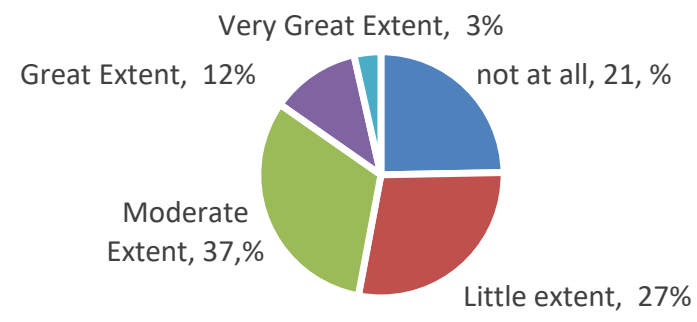

\section{Figure 4: Methods of Procurement}

The respondents were asked to indicate the descriptive responses for methods of procurement. The result revealed that majority of the respondents (3.2) agreed with the statement that using open tender plays a significant role in customer satisfaction. The responses were varied as shown by a standard deviation of 1.3. The result revealed that majority of the respondent (3.2) agreed with the statement that using restricted tendering plays a significant role in customer satisfaction. The 
International Journal of Supply Chain and Logistics

ISSN 2520-3983 (Online)

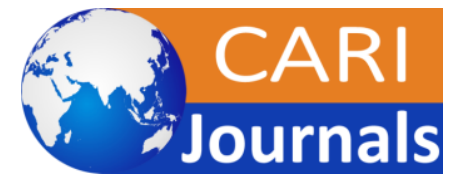

Vol. 5, Issue No.2, pp 23 - 41, 2021

www.carijournals.org

responses were varied as shown by a standard deviation of 1 . The result revealed that majority of the respondent (4.3) agreed with the statement that using direct procurement plays a significant role in customer satisfaction. The responses were varied as shown by a standard deviation of 1 .

The result revealed that majority of the respondent (4.2) agreed with the statement that using open tender plays a significant role in improving market share. The responses were varied as shown by a standard deviation of 0.8 . The result revealed that majority of the respondent (4.1) agreed with the statement that using restricted tendering plays a significant role in improving market share. The responses were varied as shown by a standard deviation of 1 . The result revealed that majority of the respondent (4.2) agreed with the statement that using direct procurement plays a significant role in improving market share. The responses were varied as shown by a standard deviation of 0.8

The result revealed that majority of the respondent (4.4) agreed with the statement that using open tender plays a significant role in increasing profitability. The responses were varied as shown by a standard deviation of 0.6. The result revealed that majority of the respondent (4.4) agreed with the statement that using restricted tendering plays a significant role in increasing profitability. The responses were varied as shown by a standard deviation of 0.6 . The result revealed that majority of the respondent (4.4) agreed with the statement that using direct procurement plays a significant role in increasing profitability. The responses were varied as shown by a standard deviation of 0.7.

The average mean response for the statements on electronic sourcing was 4.4 indicating there was agreement on electronic sourcing, the variations in the responses was 0.9. This means methods of procurement are paramount in all executive state corporations. The results imply that an organization benefits greatly when proper methods of procurement are embraced (Bird, 2019).

\section{Table 4: Methods of Procurement}

\begin{tabular}{|c|c|c|}
\hline Statements & Mean & Std. Deviation \\
\hline Using open tender plays a significant role in customer satisfaction & 3.2 & 1.3 \\
\hline Using restricted tendering plays a significant role in customer satisfaction & 2.9 & 1.0 \\
\hline Using direct procurement plays a significant role in customer satisfaction & 4.3 & 0.9 \\
\hline Using open tender plays a significant role in improving market share & 4.3 & 0.9 \\
\hline $\begin{array}{l}\text { Using restricted tendering plays a significant role in improving market } \\
\text { share }\end{array}$ & 4.1 & 1.0 \\
\hline $\begin{array}{l}\text { Using direct procurement plays a significant role in improving market } \\
\text { share }\end{array}$ & 4.2 & 0.8 \\
\hline Using open tender plays a significant role in increasing profitability & 4.4 & 0.6 \\
\hline $\begin{array}{l}\text { Using restricted tendering plays a significant role in increasing } \\
\text { profitability }\end{array}$ & 4.4 & 0.7 \\
\hline $\begin{array}{l}\text { Using direct procurement plays a significant role in increasing } \\
\text { profitability }\end{array}$ & 4.4 & 0.6 \\
\hline Average & 4.4 & 0.9 \\
\hline
\end{tabular}


International Journal of Supply Chain and Logistics

ISSN 2520-3983 (Online)

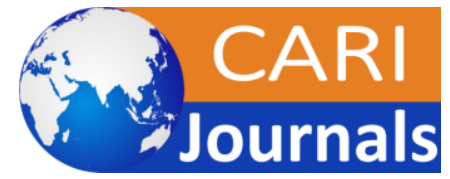

Vol. 5, Issue No.2, pp 23 - 41, 2021

www.carijournals.org

\section{2: Correlation Analysis}

Correlation analysis was used to determine both the significance and degree of association of the variables and also predict the level of variation in the dependent variable caused by the independent variables in table 5.

Table 5: Summary of Pearson's Correlations

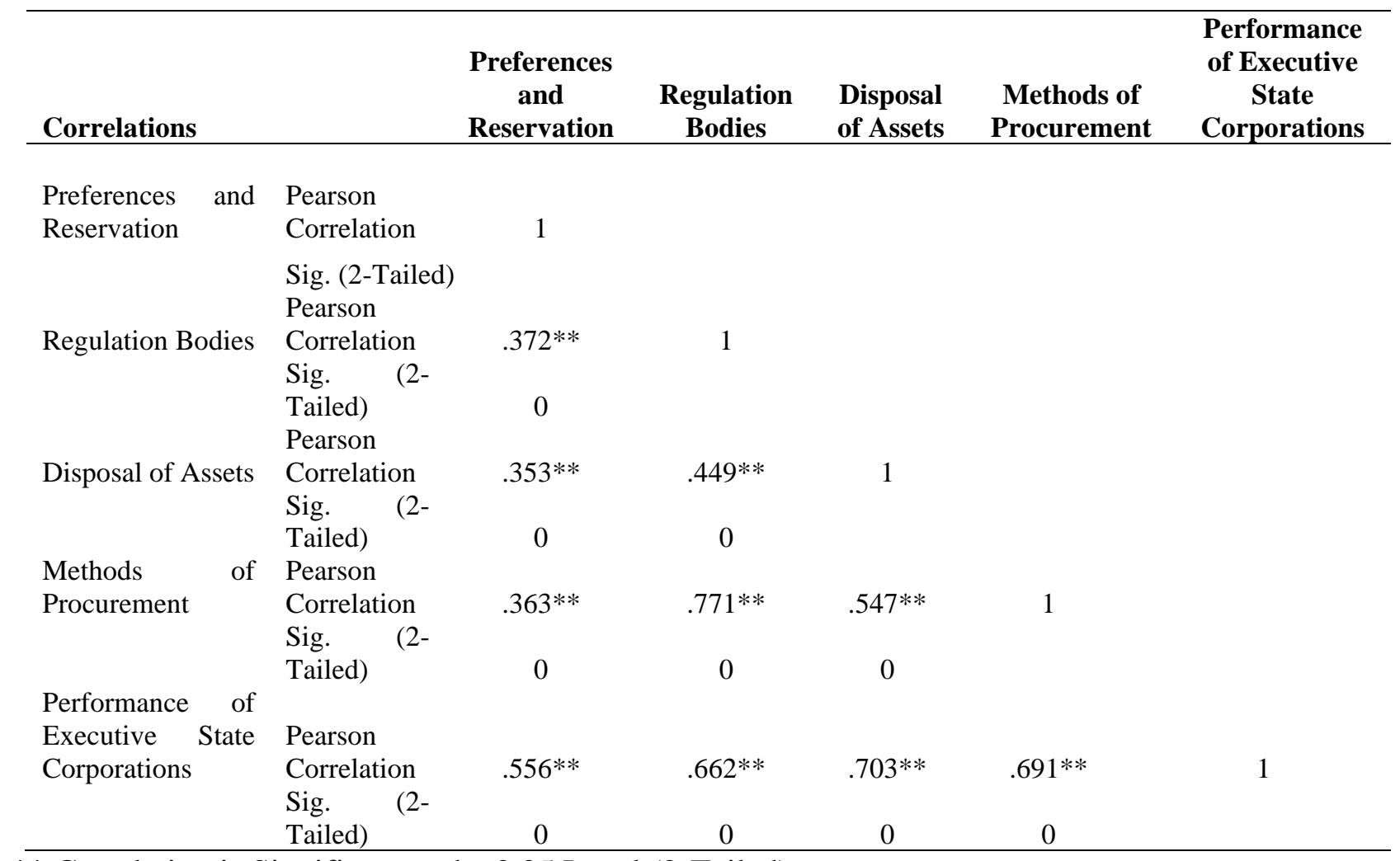

** Correlation is Significant at the 0.05 Level (2-Tailed).

The correlation summary shown in Table 5 indicated that the associations between each of the independent variables and the dependent variable were all significant at the $95 \%$ confidence level. The correlation analysis to determine the relationship between the preferences and reservation and performance of executive state corporationsin Kenya, Pearson correlation coefficient computed and tested at $5 \%$ significance level. The results indicate that there was a positive relationship $(\mathrm{r}=0.556)$ between the preferences and reservation and performance of executive state corporationsin Kenya. In addition, the researcher found the relationship to be statistically significant at $5 \%$ level $(\mathrm{p}=0.000,<0.05)$.

The correlation analysis to determine the relationship between the Regulation bodies and performance of executive state corporationsin Kenya, Pearson correlation coefficient computed and tested at 5\% significance level. The results indicated that there was a positive relationship $(\mathrm{r}=0.662)$ between the Regulation bodies and performance of executive state corporationsin 
Kenya. In addition, the researcher found the relationship to be statistically significant at $5 \%$ level $(\mathrm{p}=0.000,<0.05)$.

The correlation analysis to determine the relationship between disposal of assets and performance of executive state corporationsin Kenya, Pearson correlation coefficient computed and tested at $5 \%$ significance level. The results indicate that there was a positive relationship $(r=0.703)$ between disposal of assets and performance of executive state corporationsin Kenya. In addition, the researcher found the relationship to be statistically significant at $5 \%$ level $(\mathrm{p}=0.000,<0.05)$.

The correlation analysis to determine the relationship between methods of procurement and performance of executive state corporationsin Kenya, Pearson correlation coefficient computed and tested at $5 \%$ significance level. The results indicate that there was a positive relationship $(\mathrm{r}=.691)$. In addition, the researcher found the relationship to be statistically significant at $5 \%$ level $(\mathrm{p}=0.000,<0.05)$. Hence, it was evident that all the independent variables could explain the changes in the performance of executive state corporations in Kenya, on the basis of the correlation analysis.

\subsection{Regression Analysis}

In this study multivariate regression analysis was used to determine the significance of the relationship between the dependent variable and all the independent variables pooled together. Table 6 presented the regression coefficient of independent variables against dependent variable. The independent variables reported $\mathrm{R}$ value of 0.846 indicating that there was perfect relationship between dependent variable and independent variables. R square value of 0.715 means that $71.5 \%$ of the corresponding variation in performance of executive state corporations in Kenya can be explained or predicted by (preferences and reservation, regulation bodies, disposal of assets and methods of procurement) which indicated that the model fitted the study data. The results of regression analysis revealed that there was a significant positive relationship between dependent variable and independent variable at $(\beta=0.715), \mathrm{p}=0.000<0.05)$.

Table 7: Model Summary

\begin{tabular}{lllll}
\hline Model & R & R Square & Adjusted R Square & $\begin{array}{l}\text { Std. Error of the } \\
\text { Estimate }\end{array}$ \\
\hline 1 & $.846^{\mathrm{a}}$ & .715 & .703 & .14869 \\
\hline
\end{tabular}

a. Predictors: (Constant), Preferences and Reservation, Regulation Bodies, Disposal of Assets and Methods of Procurement

b. Dependent Variable: Performance of Executive State Corporations 
International Journal of Supply Chain and Logistics

ISSN 2520-3983 (Online)

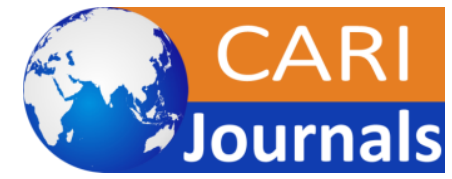

Vol. 5, Issue No.2, pp 23 - 41, 2021

www.carijournals.org

Table 8: ANOVA

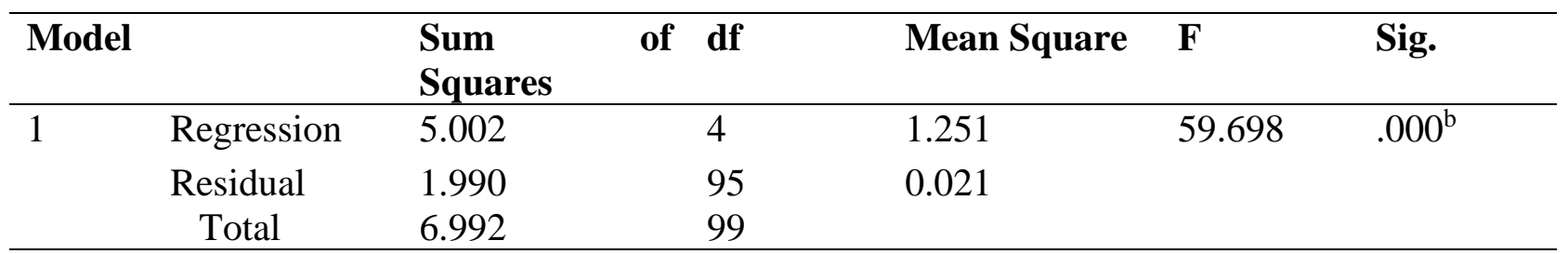

a. Predictors: (Constant), Preferences and Reservation, Regulation Bodies, Disposal of Assets and Methods of Procurement

b. Dependent Variable: Performance of Executive State Corporations

The significance value is 0.000 which is less than 0.05 thus the model is statistically significance in predicting preferences and reservation, regulation bodies, disposal of assets and methods of procurement influence performance of executive state corporations in Kenya. The F critical at 5\% level of significance was 28.61. Since F calculated which can be noted from the ANOVA table above is 59.69 which is greater than the F critical (value= 28.61), this shows that the overall model was significant. The study therefore establishes that; preferences and reservation, regulation bodies, disposal of assets and methods of procurement were all important public procurement and asset disposal Act practices influencing performance of executive state corporations. These results agree with Odhiambo and Kamau (2018) results which indicated a positive and significant influence of public procurement and asset disposal Acton performance of executive state corporations.

Table 9: Coefficients of Determination

\begin{tabular}{|c|c|c|c|c|c|c|}
\hline \multirow{2}{*}{\multicolumn{2}{|c|}{ Model }} & \multicolumn{2}{|c|}{$\begin{array}{l}\text { Unstandardized } \\
\text { Coefficients }\end{array}$} & \multirow{2}{*}{$\begin{array}{c}\text { Standardized } \\
\text { Coefficients } \\
\text { Beta }\end{array}$} & \multirow[t]{2}{*}{$\mathbf{t}$} & \multirow[t]{2}{*}{ Sig. } \\
\hline & & $\boldsymbol{\beta}$ & Std. Error & & & \\
\hline \multirow[t]{6}{*}{1} & (Constant) & 2.07 & 0.193 & & 10.725 & 0.000 \\
\hline & Preferences & 0.166 & 0.041 & 0.255 & 4.048 & 0.000 \\
\hline & Reservation & & & & & \\
\hline & Regulation Bodies & 0.138 & 0.053 & 0.235 & 2.603 & 0.001 \\
\hline & Disposal of Assets & 0.119 & 0.021 & 0.398 & 5.667 & 0.000 \\
\hline & Methods of Procurement & 0.09 & 0.043 & 0.201 & 2.093 & 0.037 \\
\hline
\end{tabular}

The research used a multiple regression model

$$
Y=\beta_{0}+\beta_{1} X_{1}+\beta_{2} X_{2}+\beta_{3} X_{3}+\beta_{4} X_{4}+\varepsilon
$$

The regression equation will be;

$$
\mathrm{Y}=2.07+0.166 \mathrm{X}_{1}+0.138 \mathrm{X}_{2}+0.119 \mathrm{X}_{3}+0.09 \mathrm{X}_{4}
$$

The regression equation above has established that taking all factors into account (preferences and reservation, regulation bodies, disposal of assets and methods of procurement) constant at zero, 
International Journal of Supply Chain and Logistics

ISSN 2520-3983 (Online)

Vol. 5, Issue No.2, pp 23 - 41, 2021

$\underline{\text { www.carijournals.org }}$

performance of executive state corporations in Kenya will be an index of 2.07. The findings presented also shows that taking all other independent variables at zero, a unit increase in preferences and reservation will lead to a 0.166 increase in performance of executive state corporations. The P-value was 0.000 which is less 0.05 and thus the relationship was significant.

The study also found that a unit increase in regulation bodies will lead to a 0.138 increase in performance of executive state corporations in Kenya. The P-value was 0.00 and thus the relationship was significant. In addition, the study found that a unit increase in disposal of assets will lead to a 0.119 increase in the performance of executive state corporations in Kenya. The Pvalue was 0.000 and thus the relationship was significant.

Lastly, the study found that a unit increase in methods of procurement will lead to a 0.09 increase in the performance of executive state corporationsin Kenya. The P-value was 0.00 and hence the relationship was significant since the $\mathrm{p}$-value was lower than 0.05 . The findings of the study show that, preferences and reservation contributed most to the performance of executive state corporations in Kenya.

\subsection{SUMMARY, CONCLUSION AND RECOMMENDATIONS}

\subsection{Summary of the Findings}

The study sought to examine the influence of public procurement and asset disposal Act on performance of executive state corporations in Kenya. The study endeared to determine the influence of public procurement and asset disposal Act on performance of executive state corporations in Kenya. The regression results revealed that public procurement and asset disposal Act aspects identified in the study, that is, preferences and reservation, regulation bodies, disposal of assets and methods of procurement combined could explain approximately $71.5 \%$ of the variations in the performance of executive state corporations. The other $28.5 \%$ may be attributed to other public procurement and asset disposal Act aspects not explained by the model or the variables. From inferential statistics, a positive correlation is seen between each predictor variable and performance of executive state corporations. The strongest correlation was established between the preferences and reservation and performance of executive state corporations. All the independent variables were found to have a statistically significant association with the dependent variable at ninety-five percent level of confidence.

\subsection{Conclusion}

Based on the study findings, the study concludes that performance of executive state corporations can be improved by preferences and reservation, regulation bodies, disposal of assets and methods of procurement.

\subsection{Recommendations}

the study recommended that public institutions should embrace regulation bodies, methods of procurement, preferences and reservations and disposal of assets so as to improve performance of executive state corporations and further researches should to be carried out in other public institutions to find out if the same results can be obtained. 
International Journal of Supply Chain and Logistics

ISSN 2520-3983 (Online)

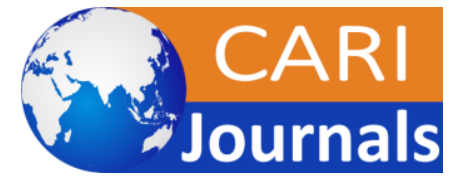

Vol. 5, Issue No.2, pp 23 - 41, 2021

www.carijournals.org

\section{REFERENCES}

Amayi, F. (2011). Factors Affecting Procurement in the Public Service: a Case Study of the State Law Office. Eldoret: Moi University.

Christine, A. (2010). Public procurement as a lever of government reform: International Journal on Scientific Research.

Comesa Public Procurement Reform Procurement (2014). African Regional workshop on harmonization alignment and results, retrieved from http:/www.worldbankorg/ on $14^{\text {th }}$ June 2018.

Mahmood, S.A. (2010). Public Procurement and Corruption in Bangladesh. Confronting the Challenges and Opportunities. Journal of Public Administration and Policy Research, 2(6), 103-111.

Makau, J.K. (2012). "Challenges facing adoption of electronic procurement in public sector in Kenya: A case of Nairobi Water and Sewerage Company". International Journal of Social Sciences and Entrepreneurship, 1(11), 267-286.

Malik, A., \& Yong, J. (2010). TQM practices \& organizational performance: Evidence from Tanzania SMEs, International Journal of Engineering \& Technology, 10(4), 26-31.

Mann, S., \& Zhang, T. (2010). Some cultural/geographical styles in strategies and costs (P.R.

Mugenda, O., \& Mugenda, A. (2014). Research methods quantitative and qualitative approaches. Nairobi: Acts Press.

Neuman, W.L. (2010). Social Research Methods: Qualitative and Quantitative Approaches (Fourth Edition ed.) Boston.

Ngechu, M. (2011). Understanding the Research Process and Methods. An Introduction to Research Methods. Acts press, Nairobi.

Nwabueze, U. (2011). An industry betrayed: the case of total quality management in manufacturing, International Journal of Human Resource and Research Publication, 13(6), 20-48.

Patron, M. (2012). Qualitative Research and Evaluation Method (3ed.). London: Sage Publication Performance.

Paul, S. (2011). Procurement policies in public corporations. Journal of Purchasing, 3(6), 4-24.

PPOA (2010). Assessing Procurement Systems in Kenya Report. Nairobi: Public Oversight Authority.

PPOA (2010). Assessment of the Procurement System in Kenya Report. A report by Public Procurement Oversight Authority, Nairobi.

Procurement Reform Procurement (2014). African Regional Workshop on Harmonization, Alignment and Results, available on http:/www.worldbankorg/ on 14th June, 2018. 
International Journal of Supply Chain and Logistics

ISSN 2520-3983 (Online)

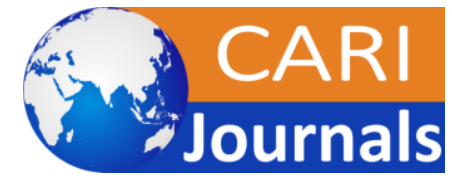

Vol. 5, Issue No.2, pp 23 - 41, 2021

$\underline{\text { www.carijournals.org }}$

Rambo, C.M. (2012). Procurement Reforms and Expenditure Management in Public Secondary Schools. Nairobi: DBA African Management Review Publishers.

Rotich, L.M. (2011). Influence of Planning on Procurement Performance in the Kenya, International Journal of Human Resource and Research Publication, 1(2), 289-292.

Rouse, M. (2013). Definition of best public procurement management, Related glossary terms. Updated September, 2016.

Rudzki, R. A., \& Trent, R. J. (2011). Next level supply management excellence: Your straight to the bottom-line roadmap. Ft. Lauderdale, FL: J. Ross Pub.

Saunders, M. (2012). Research for business students (6 ed.). Financial Times Prentice Hall. 